\title{
EKONOMICZNE I SPOLECZNE ASPEKTY KONKURENCJI PODATKOWEJ W UNII EUROPEJSKIEJ
}

\section{WSTĘP}

Podczas szczytu G8 w czerwcu 2013 r. zwrócono szczególną uwagę na kwestie związane $\mathrm{z}$ unikaniem podatków przez przedsiębiorstwa prowadzące działalność gospodarczą w danym kraju - na ucieczkę do innych, definiowanych jako „raje podatkowe” ${ }^{1}$ domicyli podatkowych. Oczekiwanie, by firmy płaciły podatki tam, gdzie uzyskuja dochody, a nie tam, gdzie mają swą zarejestrowaną siedzibę, jest jednym z kluczowych postulatów państw wysoko rozwiniętych. Argumentem przeciwnym jest z reguły obawa przed migracją kapitału do innych państw. O ile jednak migracja taka może być istotna tam, gdzie o lokalizacji decyduje koszt funkcjonowania (głównie działalności produkcyjnej), o tyle obawa przed ucieczka kapitału handlowego do innych krajów wydaje się absurdalna. W tym wypadku o lokalizacji inwestycji decyduje nie koszt funkcjonowania, ale wartość lokalnego rynku definiowana popytem i zamożnością potencjalnych klientów. Słuszne więc wydają się działania np. premiera Węgier Viktora Orbána - obciążenie dodatkowo m.in. 1-procentowym podatkiem obrotowym (od kwoty obrotu powyżej 2 mln euro) sieci handlowych czy 6,5-procentowy podatek obrotowy narzucony na sieci handlowe.

Fakt konkurencji podatkowej państw jest jednak istotny tam, gdzie inwestuje się w działalność produkcyjna, zwłaszcza przeznaczoną na eksport. $\mathrm{Na}$ tym polu rywalizują również poszczególne państwa Eurolandu.

Poza tym również w poszczególnych państwach może występować zróżnicowanie terytorialne w wysokości stawek podatkowych, i to nie tylko tych, których wysokość wyznaczania znajduje się w wyłącznej kompetencji władz samorzadowych. Przykładem mogą być tu polskie specjalne strefy ekonomiczne.

Efektem konkurencji podatkowej między poszczególnymi państwami UE jest występowanie różnic w stawkach, ulgach i sposobie poboru podatków. Ma to szczególne znaczenie w sytuacji migracji inwestycyjnego kapitału finansowego (powiązanego z inwestycjami bezpośrednimi), będącej skutkiem nasi-

\footnotetext{
${ }^{1}$ Szerzej na temat polityki rajów podatkowych m.in. w: L. Michalczyk, Gospodarcza i prawna istota cen transferowych w Polsce, „Pieniądze i Więź” 2011, nr 3 (52), s. 90-110; idem, Wykorzystanie akumulacyjnej funkcji struktur offshore $w$ realiach polskiego prawa podatkowego, „Pieniądze i Więź" 2011, nr 4 (53), s. 141-153.
} 
lania się tendencji globalizacyjnych ${ }^{2}$ „darwinizmu ekonomicznego” ${ }^{3} \mathrm{w}$ gospodarce i stosunkach społecznych. Za oczywisty należy uznać fakt, że kierujące się wynikiem ekonomicznym netto przedsiębiorstwo będzie inwestować tam, gdzie podatki są niższe. Przy czym cechą charakterystyczną globalizmu jest podporządkowanie procesów społeczno-ekonomicznych interesom mikroekonomicznym przedsiębiorstw ${ }^{4}$. Rozwój międzynarodowych stosunków gospodarczych skutkujaccych powstaniem globalizmu w relacjach pomiędzy podmiotami gospodarczymi oraz podmiotami gospodarczymi a państwem spowodował przewartościowania również na gruncie dominujących ideologii i relacji społecznych. W globalizmie totalitaryzmy: filozoficzny (starożytność), religijny ('́redniowiecze), sztuki (odrodzenie), nauki (oświecenie), polityki (XIX-XX w.) zostały zastapione totalitaryzmem gospodarczym.

Skutkiem tych tendencji jest coraz większe odrywanie się wielkiego biznesu od „przynależności narodowej” w prowadzonej przez siebie działalności gospodarczej. Celem staje się nie wspieranie rodzimych społeczności ale maksymalizowanie zysku korporacji. Dlatego też, by stać się konkurencyjnymi $\mathrm{w}$ pozyskiwaniu międzynarodowego oraz zatrzymaniu rodzimego kapitału inwestycyjnego ${ }^{5}$, poszczególne państwa stosować muszą specjalne rozwiązania, tzn. pakiety ulg, zwolnień, dotacji czy subwencji z reguły pośrednio powiązanych z konkretnym biznesem. Ta „pośredniość” wynika z obostrzeń w prawie unijnym i powiązana jest z reguły z subwencjami z budżetu centralnego dla samorządów lokalnych w celu budowy np. infrastruktury okołobiznesowej. Działanie takie umożliwia przyjęty powszechnie w Europie

${ }^{2}$ Por.: J. E. Stiglitz, Szalone lata dziewięćdziesiate. Nowa historia najświętszej dekady w dziejach świata, PWN, Warszawa 2006; idem, A. Charlton, Fair trade. Szansa dla wszystkich, PWN, Warszawa 2007; J. A. Scholte, Globalizacja, Humanites, Sosnowiec 2006.

${ }^{3}$ B. Janik, Kapitalizm w ujęciu dynamicznym. Od państwa dobrobytu do globalizacji, Wyd. AŚ, Kielce 2006, s. 204.

${ }^{4} \mathrm{~W}$ nauce odróżnia się pojęcie globalizmu od globalizacji. Pierwsze jest działaniem „oddolnym” związanym z ekspandowaniem wolnego rynku w postaci dyfuzji jego struktur. Wykorzystanie uwarunkowań rynków kapitałowych na rynkach światowych umożliwia prywatnemu biznesowi uzyskanie autonomiczności i rozdzielenie kapitału między kraje realizujące jego priorytety. Głównym priorytetem jest lokalizacja kapitału w państwach, w których nie ma „barier brzegowych” narzuconych przez państwo „prywatnej inicjatywie”. Globalizm, zdaniem np. J. E. Stiglitza, Ekonomia sektora publicznego, PWN, Warszawa 2004, s. 48-49, jest konsekwencją działań MFW, BŚ czy WTO i jest przejawem implementacji do rzeczywistości gospodarczej leseferyzmu. Globalizacja jest powiązania z szerzeniem się powiązań międzyludzkich i ma bardziej socjologiczny niż ekonomiczny charakter w porównaniu z globalizmem. Ideologicznym „wrogiem” globalizmu jest konstrukcja „państwa dobrobytu”. Z kolei „państwo dobrobytu” było konsekwencją strachu kapitalistów przed „wywiezieniem ich na taczkach” na wzór wydarzeń z Rosji 1. 1917-1920, jednak nadal jest to państwo kapitalistyczne.

${ }^{5}$ Zgodnie z koncepcjami finansów behawioralnych strata (tu: emigracja uznanego za rodzimy kapitał) jest postrzegana gorzej niż proporcjonalnie równy jej, oczywiście z odwrotnym „znakiem”, zysk (imigracja obcego kapitału). Tymczasem np. w Polsce występowało istotne zróżnicowanie m.in. w prawnopodatkowym traktowaniu kapitału zagranicznego w stosunku do rodzimego. Inwestycjom zagranicznym, nawet gdy nie tworzyły istotnej wartości dodanej, a wręcz powodowały likwidację przejętych zakładów, przyznawano wieloletnie zwolnienia podatkowe - mechanizmy, których (z wyjątkami) nie stosowano w wypadku rodzimego kapitału. Na fakt braku adekwatności ulg podatkowych z działaniami pozwalającymi na wchłanianie przez rynek nadwyżek siły roboczej zwrócił uwagę m.in.: J. Tittenbrun, $Z$ deszczu pod rynnę. Meandry polskiej prywatyzacji, t. 1-4, Poznań 2007. 
francuski system poboru i rozdysponowywania środków pieniężnych pochodzących z podatków. System ten polega na centralnym gromadzeniu dochodu budżetowego a następnie rozdysponowywaniem go na cele realizowane z reguły przez jednostki samorządowe w postaci subwencji bądź na „ogólne utrzymanie" w postaci dotacji ${ }^{6}$.

Stosując zasady konkurencji podatkowej w walce o BIZ (bezpośrednie inwestycje zagraniczne), państwa wprowadzaja do swych rozwiązań prawnopodatkowych systemy pozwalające na zakwalifikowanie do tzw. nieuczciwej konkurencji podatkowej ${ }^{7}$, stosuja również działania obejmujące ulgi dla wybranych grup przedsiębiorców ${ }^{8}$. W dalszej części niniejszego artykułu omówiono kilka takich przypadków, szczególną uwagę zwrócono na polskie specjalne strefy ekonomiczne (SSE), które odpowiadać mogą zasadom funkcjonowania „rajów podatkowych”, a zlokalizowane na ich obszarze przedsiębiorstwa strukturom offshore business.

Jak dotąd w UE ujednolicano podatki pośrednie, zresztą na tyle nieudolnie, że nie tylko nie zrównano poszczególnych stawek, ale wręcz pozostawiono systemy stawek „ulgowych”, „obniżonych”, „zredukowanych”, „preferencyjnych” itp.

\section{KONKURENCJA PODATKOWA W KONTEKŚCIE POSTULATÓW TRAKTATU LIZBOŃSKIEGO}

Wszelkie dyskusje związane z podatkami z reguły koncentrują się na jednej (co najmniej) z trzech kwestii:

- sprawiedliwości w zakresie stawek, sposobów poboru oraz rozchodowania pozyskanych z tego źródła pieniędzy,

- efektywności analizujacej ich społeczno-gospodarcze oddziaływanie,

- struktur administracyjnych zaangażowanych w pobór podatków oraz kosztów ich poboru.

Postulaty traktatu lizbońskiego z 2007 r., a wcześniej - traktatu konstytucyjnego Europy z 2004 r., wprowadziły do „europejskiego prawa gospodarczego" dwie kwestie:

\footnotetext{
${ }^{6}$ Alternatywny model poboru podatku, model brytyjski, polega na gromadzeniu dochodu podatkowego w jednostkach samorządowych (tu: hrabstwach) i przekazywaniu proporcjonalnej jego części, z reguły identycznych procentowo części w budżecie każdego z hrabstw, na realizowanie celów przez rząd centralny (obronność, sprawy zagraniczne, niemunicypalna policja krajowa, szkolnictwo wyższe, administracja centralna, itp.). System ten jednak się nie przyją mimo swej długoletniej tradycji. W Polsce system ten, rozważany w okresie międzywojennym, wywoływał złe skojarzenia z permanentnym brakiem wystarczających środków w budżecie polskiej monarchii elekcyjnej i równoczesnych znacznych dochodach pozostawionych w systemie prowincjonalnym. System francuski obowiązuje w całej kontynentalnej Europie, z wyjątkiem Niemiec (podatek przekazują landy pobierające go bezpośrednio od podatników) i Szwecji (państwo dysponuje podatkami od kapitału, wyznaczanie wysokości i pobór podatków dochodowych znajduje się w dyspozycji länów) - szerzej: S. Bratkowski, O barierach rozwoju, marnotrawstwie i etyce służby publicznej, w: S. Rudolf (red.), Sektor finansowy - dylematy i kierunki rozwoju, Warszawa 2008.

${ }^{7}$ Sformułowanie za: polskim prawodawstwem dot. rajów podatkowych.

${ }^{8}$ M. Księżyk, Prorozwojowe zachęty inwestycyjne w Hiszpanii i Wielkiej Brytanii, „Ekonomia i Środowisko" 2002, nr 1 (21).
} 
- społecznej gospodarki rynkowej,

- działań prorozwojowych w kierunku tworzenia przesłanek dla zrównoważonego rozwoju gospodarczego.

Aby osiagnąć powyższe cele, podatki, ich stawki (skale, ulgi i zwolnienia), sposoby poboru moga być definiowane jako elementy polityki gospodarczej w mniejszym lub większym stopniu wpływające na:

- „definicyjny” dobrobyt społeczny,

- konkurencyjność zarówno Unii, jak i poszczególnych jej krajów na zewnątrz.

$\mathrm{W}$ powyższych aspektach postrzeganie czynności państwowych $\mathrm{w}$ sferze podatkowej nabiera szczególnego znaczenia. Nie można bowiem abstrahować od potrzeby maksymalizowania przychodów budżetowych i tworzenia układów zwalczających konkurencję podatkową państw członkowskich. Ideałem byłby system podatkowy o identycznych stawkach, identycznym pakiecie zwolnień i ulg. System taki jest jednak abstrakcja. Ponadto z góry skazywałby na niepowodzenie gospodarcze państwa, w których inne czynniki promowania rozwoju gospodarczego byłyby różne, a trudno przypuszczać, by np. Polska czy Rumunia mogły konkurować z Niemcami pod względem chociażby rozwoju infrastruktury komunikacyjnej. Niemniej wydaje się, że wolna konkurencja systemów podatkowych coraz częściej staje w sprzeczności z rozumieniem idei „rynku europejskiego” w świetle traktatu lizbońskiego. Działania podatkowo czy dotacyjnie promujące dany kraj moga spotkać się z unijnymi pośrednimi karami finansowymi (np. odebranie przyznanej wcześniej subwencji unijnej).

Problematyka podatków w jej społeczno-gospodarczo-finansowym ujęciu znajduje swe odbicie w szerokiej literaturze prawniczej, ekonomicznej czy socjologicznej, a także np. historycznej czy psychologicznej. Kluczowe rozważania w tym zakresie dotyczyły:

- sposobów poboru podatków,

- analiz związanych z ich wysokością w aspekcie opłacalności działalności gospodarczej i maksymalizacji dochodów budżetowych,

- sposobów rozdysponowania podatków,

- społecznego charakteru podatków w powiązaniu z minimalizowaniem dysproporcji dochodowych między poszczególnymi obywatelami jako celu zmierzającego do utrzymania porządku (i spokoju) społecznego ${ }^{9}$.

Sygnalizowanym celem jest tu „maksymalizowanie dobrobytu społecznego" ${ }^{10}$. Z definicji warunkiem sine qua non „maksymalizowania dobrobytu społecznego" jest taki system podatkowy, który stymulowałby wzrost gospodarczy. Pochodną wzrostu gospodarczego powyżej wskaźników będących wartością wynikająca ze wzrostu udziału technologii oraz wzrostu wydajności pracy we wzroście gospodarczym jest wzrost liczby miejsc pracy. Skutkuje on w zasadzie spadkiem bezrobocia, jeśli nie prowadzi do powstania zwiększonych rzesz osób pracujących na wielu etatach lub klasyfikowanych jako

9 Por. K. Wach, Systemy podatkowe krajów Unii Europejskiej, Oficyna Ekonomiczna, Kraków 2005; G. Szczodrowski, Polski system podatkowy, PWN, Warszawa 2007.

10 J. E. Stiglitz, Ekonomia..., s. 662. 
„poza strukturą potencjalnych pracobiorców” (emeryci/renciści, studenci, rolnicy itp.). Spadek bezrobocia, co do zasady, wpływa pozytywnie zarówno na budżety domowe obywateli, jak i na wielkość budżetu państwa (samorządów) przez kreowanie nowych grup osób objętych obowiązkiem podatkowym, a także zmniejszenie ilości osób będących beneficjentami wydatków z funduszy społecznych. Zgodnie z modelową konstrukcja Johna M. Keynesa pojawienie się większej ilości dyspozycyjnej gotówki u większej grupy populacji zwiększa poziom popytu globalnego, jest więc czynnikiem stymulującym rozwój gospodarczy. Winno to też sprzyjać zmniejszaniu „wad systemu kapitalistycznego” związanych z nierównomiernym rozkładem dochodów w populacji i występującym bezrobociem ${ }^{11}$.

Również konstrukcja podatkowych „ulg inwestycyjnych” jako stymulatora rozwoju gospodarczego nie jest nową koncepcją w nauce. To, co dziś wydaje się oczywiste, ponieważ wynika z istoty kapitalizmu i czysto zdroworozsądkowego podejścia „matematyki szkoły podstawowej”: więcej mamy, jeśli mniej wydamy (na podatki) lub jeśli państwo nam zwróci albo da, wiąze się z poglądami Michała Kaleckiego. Konstrukcja „obniżki podatku dochodowego, [...] i subsydiowania przedsiębiorstw podejmujących inwestycje"12 odpowiada strukturze rajów podatkowych czy też będących ich odpowiednikiem w Polsce: specjalnych stref ekonomicznych ${ }^{13}$.

Koncepcja „walki z dysproporcjami dochodowymi obywateli” sięga początków ubiegłego wieku i jest pokłosiem wydarzeń w Rosji z drugiej dekady tegoż wieku oraz ruchów robotniczych, które ogarnęły Europę po I wojnie światowej jako następstwo wyzysku gospodarczego oraz pogardy dla słabszych ekonomicznie członków społeczeństwa ${ }^{14}$. Obawa przed podobnymi wydarzeniami spowodowała powstanie progresywnych systemów podatkowych w Europie ${ }^{15}$.

\footnotetext{
${ }_{11}$ J. M. Keynes, Ogólna teoria zatrudnienia, procentu i pieniadza, PWE, Warszawa 2003, s. 351.

${ }^{12}$ Koncepcja zaproponowana wtedy przez M. Kaleckiego znalazła też uznanie u guru ekonomistów „postkryzysowych '29 r.”, J. M. Keynesa - por. M. Kalecki, Dzieła, t. 1, Warszawa 1979, s. 572 , podobnie s. $275-276$ i 375.

${ }^{13}$ Podobnie obowiązujące do 2009 r. przepisy rozporządzeń dotyczących obszarów o strukturalnym bezrobociu oraz zdegradowanych społecznie, gospodarczo i ekologicznie, umożliwiające np. przyspieszenie amortyzacji zakupionych urządzeń i maszyn. Jednak sens obniżenia podatku przez zwiększenie amortyzacji wobec realizacji celu, jakim miałoby być ograniczenie bezrobocia, wydaje się wątpliwy od strony logicznej. Zwiększenie uprzedmiotowienia stanowisk pracy jest w opozycji do siły roboczej (ilości miejsc pracy) - o czym wiedziano już w XVIII w. W sensie tej ustawy bardziej opłacało się pracodawcom kupić nowe maszyny i zwolnić już zatrudnionych pracowników, niż zatrudniać kolejne osoby. By uzyskać zamierzony efekt społeczny, nie należało obniżać podatki przez zmniejszenie amortyzacji, ale obniżyć je przez zmniejszenie narzutu na koszty pracy. Logika działania polskiego rządu nie od dzisiaj nasuwa jednak wiele uwag krytycznych. Chyba że celem ukrytym była możliwość dania dodatkowego zarobku kolesiom - czego też wykluczyć nie można - por. L. Michalczyk, Umorzenie a amortyzacja w aspekcie rachunkowościowej ochrony obrotu gospodarczego, w: B. Micherda (red.), Rachunkowość w ochronie obrotu gospodarczego, Wyd. AE w Krakowie, Kraków 2005, s. 207-221.

${ }^{14}$ L. Michalczyk, CSR w pierwszej dekadzie XXI w., „Pieniądze i Więź” 2011, nr 2 (51), s.14.

${ }^{15}$ Uważa się, że historycznie, biblijnie pierwotnym był podatek liniowy, dziesięcina (10\%), chociaż początek podatków dochodowych to trzynastowieczna Aragonia, podatku VAT - weimarskie Niemcy, a dochodowego podatku progresywnego - Europa pierwszej połowy XX w.
} 
W tym ujęciu od kilku lat największe zróżnicowanie dochodów wśród krajów UE występuje w Portugalii i w Polsce ${ }^{16}$.

Rozbudowa systemów podatkowych co do zasady powoduje wzrost administracji. Pomijając komizm prawa Parkinsona (o „wzroście administracji”), należy zwrócić uwagę, że ograniczenie dystrybucji podatków między urzędami (pozostawienie ich $\mathrm{w}$ miejscu pobrania na cele realizowane przez pobierajacych) obniżyłoby koszty obsługi administracyjnej systemu dystrybucji dochodów z podatków o kwoty rzędu 10-15\% ${ }^{17}$, przy równoczesnym znacznym ograniczeniu ilości zatrudnionych urzędników ${ }^{18}$.

Realizacja postulatów traktatu lizbońskiego wymagałaby jednak stworzenia takiego systemu prawnego, który blokowałby odpływ kapitału inwestycyjnego przynajmniej z UE jako całości oraz uniemożliwiałby napływ kapitału spekulacyjnego na rynki finansowe krajów członkowskich. Tego typu mechanizmy stworzyły np. Chiny ${ }^{19}$, mechanizmy te sa jednym z czynników wysoko lokalizujących tę gospodarkę w rankingach stabilności oraz chronią je przed zawirowaniami gospodarczymi w okresie niekorzystnych faz koniunkturalnych (kryzysów). Porównanie sytuacji Chin i UE w świetle założeń traktatu lizbońskiego ukazuje również, że w UE nie tworzy się systemów ukierunkowujących strumień inwestycji prywatnego biznesu w te sektory gospodarki, które uznano za najistotniejsze ze społecznego punktu widzenia.

Głównym celem pozyskiwania kapitału inwestycyjnego jest zwiększanie liczby miejsc pracy. Takie ujęcie „wzrostu przedsiębiorczości” jest zgodne z programem „Europejska strategia zatrudnienia” definiujacym cztery filary wzrostu zamożności (dobrobytu) społeczeństw ${ }^{20}$.

1. Stymulowanie rozwoju przedsiębiorczości przez systemy pomocy i ułatwienia w prowadzeniu działalności gospodarczej przede wszystkim w sektorze MŚP. Celem ma być: zwiększanie miejsc pracy jako pochodna rozwoju poszczególnych firm sektora. Narzędziami tej koncepcji są: zmniejszanie obciążeń podatkowych, szkolenia zawodowe, dostęp do zewnętrznych źródeł finansowania.

2. Zwiększanie „produktywności” osób bezrobotnych. Cel to dostosowywanie potencjalnych możliwości osób obecnie i w niedalekiej przyszłości poszukujących pracy do wymagań rynku pracy. Narzędziami są wynikające z uwarunkowań lokalnych rynków pracy inwestycje w kapitał ludzki.

3. Przystosowywanie obu ,stron” rynku pracy (pracobiorców i pracodawców) do zmian na rynku pracy. Celem jest uniknięcie marginalizacji społecznej poszczególnych grup populacji oraz powstawania bezrobocia strukturalnego. Narzędziami są przede wszystkim adekwatne programy szkoleniowe oraz promujące zatrudnienie w sektorze nowoczesnych technologii.

${ }_{16}$ Analiza poziomu wynagrodzeń prezesów firm w Polsce. Por. również: E. Polak, Globalizacja a zróżnicowanie społeczno-ekonomiczne, Difin, Warszawa 2009, s. 9 i n.

${ }_{17}$ M. Otte, Kiedy nadchodzi kryzys. Co powinniśmy zrobić, aby wyjść obronna ręka z obecnego kryzysu gospodarczego, Wyd. Studio EMKA, Warszawa 2009.

18 Ibidem, s. 236.

${ }^{19}$ Nie od dzisiaj uważa się, że środek ciężkości gospodarki globalnej przenosi się na Daleki Wschód. Od kilku lat w jego centrum są Chiny.

${ }^{20}$ Por. M. Księżyk, Ograniczenia bezrobocia w strukturze celów społeczno-gospodarczych Polski, w: D. Kopycińska (red.), Konkurencyjność rynków pracy i jego podmiotów, Szczecin 2005, s. 105-123. 
4. Deklarowana równość szans na rynku pracy w odniesieniu do kobiet, osób w wieku przedemerytalnym i osób niepełnosprawnych. Narzędziami sa instytucje propagujące zatrudnienie tych osób ${ }^{21}$.

Traktat lizboński w analizowanym obszarze zwrócił uwage na możliwości regulacyjne państw w gospodarce w zakresie występowania różnic w wysokości stawek podatkowych. Kwestia „regulacyjności” gospodarki przez państwo wzbudza szereg kontrowersji. Z zasady przeciwni sa jej liberałowe, niemniej za obecnością państwa opowiadają się te kręgi nauki i praktyki gospodarczej, które dostrzegaja problemy tworzone w gospodarce przez tzw. wolny rynek. Michela Camdessus (MFW), zadeklarowany zwolennik liberalizmu dostrzegał zagrożenia tworzone przez „rynek”22 zmierzający do monopolizacji. Monopolizacja bez udziału państwa powoduje „cofnięcie się” do realiów XIX w.: wyzysku i pogardy dla ludzi realiów, które do prowadziły do fali zamieszek w Europie w końcu drugiej dekady XX w., a więc takiej polaryzacji poglądów, antagonizmów społecznych, do których dopuszczenie skutkowałoby zamieszkami społecznymi.

Odmienności działań „wolnej ręki rynku” w porównaniu z teoretycznymi liberalistycznymi modelami dowiodły badania m.in. Gerenda Debreu i Kennetha Arrowa. Odmienności te wynikają z dużej liczby niewykonalnych w praktyce założeń w koncepcji teoretycznej wolnego rynku ${ }^{23}$. Koncepcja ta nie jest pozbawiona logiki, ale jest zarazem nazbyt życzeniowa, co powoduje, że wystarczy, by jedne z podmiotów zaczęły grać według innych reguł, by cały system się załamał. Jednocześnie koncepcja ta na tyle wyklucza państwo z „udziału w grze”, że nie posiada ono wystarczających narzędzi, aby kontrolować zachowanie wspomnianych „reguł gry”. Prowadzi to w prostym kierunku do powstawania oligopoli, a nawet monopolizacji poszczególnych sektorów gospodarki przez prywatny biznes.

\section{PODSTAWOWE STAWKI PODATKOWE W WYBRANYCH PAŃSTWACH UE}

W analizowanym aspekcie podatkowym (podatki dochodowe i VAT), system podatkowy każdego ze współczesnych państw złożony jest z podatków:

1) bezpośrednich - będących narzutem na uzyskiwane dochody,

2) pośrednich - będących narzutem na wartość sprzedaży.

W ramach działalności gospodarczej podatki bezpośrednie dotyczą zarówno przedsiębiorców jak i pracowników. W kwestii założeń traktatu lizboń-

${ }^{21} \mathrm{~Np}$. parytety zatrudnienia osób niepełnosprawnych. Analiza absurdalności tych programów w sytuacji niskiej produktywności i niechęci do podjęcia pracy przez osoby „niepełnosprawne" na zbliżonych warunkach co dla osób pełnosprawnych - por. L. Michalczyk, Zatrudnienie osób niepetnosprawnych $w$ przedsiębiorstwach województwa małopolskiego, „Gospodarka Narodowa” 2011, nr 1-2, s. 105-118.

${ }_{22}^{2}$ Za: B. Janik, Kapitalizm w ujęciu dynamicznym. Od państwa dobrobytu do globalizacji, Wyd. AŚ, Kielce 2006, s. 90 i n.

${ }^{23}$ J. E. Stiglitz, Ekonomia..., s. 40 i n. 
skiego należy od razu stwierdzić, że podatki liniowe od dochodów pracowniczych nie sa możliwe w dzisiejszej sytuacji gospodarczej w Polsce ${ }^{24}$. Wynika to z faktu, że ich funkcja jest połączenie:

- maksymalizacji dochodów budżetu państwa,

- ochrony wynagrodzeń netto przed spadkiem poniżej poziomu definiowanego jako „płaca godziwa”

Poziom „płacy godziwej”" Komitet Ekspertów Rady Europejskiej ustalił w wysokości $68 \%$ przeciętnej płacy w gospodarce danego kraju oraz postulował jej relatywny wzrost wynikajacy ze wzrostu wydajności pracy. Zdaniem chociażby Josepha E. Stiglitza takie ujęcie kwestii zarówno płacy minimalnej, jak i powiązanej z nią progresywnej skali podatkowej można by uznać za przejaw sprawiedliwości społecznejej ${ }^{26}$ - globalizmu z ludzka twarzą. W tym aspekcie za skandal można uznać obciążenie podatkiem dochodowym wynagrodzeń na poziomie płacy minimalnej, nieprzekraczającej 40-45\% przeciętnego wynagrodzenia w naszym $\mathrm{kraju}^{27}$.

$\mathrm{Na}$ tle UE polski system podatkowy od dochodów z tytułu świadczenia pracy charakteryzuje się promowaniem osób o wyższych dochodach w stosunku do osób o dochodach niższych ${ }^{28}$. W innych krajach UE zasadami sa:

- występowanie stawek 0\% dla dochodów w niższym lub niższych progach,

- stosunkowo niskie stawki dla pierwszych, stosunkowo wysokich progów,

- drastyczne, przekraczające w niektórych wypadkach 50\% podatki dla osób o najwyższych dochodach. Ich wysokość prezentuje tabela 1.

Spośród krajów UE tylko 4, i to wyłącznie te, które charakteryzują się stosunkowo niskim poziomem rozwoju gospodarczego, wprowadziły liniowa stawkę podatkową (Estonia, Łotwa, Rumunia i Słowacja).

${ }^{24} \mathrm{Na}$ temat potrzeby tworzenia progów podatkowych od podatków dochodowych pracowników wypowiadał się już jeden z guru liberałów J. S. Mill, zwracając uwagę, że dla jednych podatek oznacza pozbycie się środków na wydatki luksusowe, a dla innych - na wydatki związane z egzystencją biologiczną (idem, Zasady ekonomii politycznej, Warszawa 1966, s. 586). Podobnego zdania, sięgając do klasyków myśli liberalnej w ekonomii, byli też chociażby Rawls, czy pośrednio Petty, zwolennik wyłącznie podatków od konsumpcji (za: H. Landreth, D. C. Colander, Historia myśli ekonomicznej, Warszawa 2005, s. 83-84).

${ }^{25}$ Historycznie pojęcie to nawiązuje m.in. do A. Smitha, który w „trosce” o odtwarzanie się kolejnych pokoleń siły roboczej postulował minimalna płacę na poziomie podwójnych kosztów utrzymania - by robotnik był w stanie wychować dwoje dzieci w celu odtworzenia kolejnego pokolenia robotników (A. Smith, Badania nad naturq i przyczynami bogactwa narodów, Warszawa 1954, s. 87-88]. Na gruncie Polski XIX w. to akurat nie miało większego znaczenia, zważywszy na stały dopływ ludności ze wsi do ośrodków przemysłowych Łodzi, Warszawy czy Katowic, tak więc tradycją stały się wynagrodzenia minimalne na poziomie minimum socjalnego typowej dla naszej populacji rodziny, niepozwalające na odtworzenie „pokoleń robotniczych” - por. również: L. Michalczyk, Zatrudnienie..., s. 11.

${ }^{26}$ J. E. Stiglitz, Wizja sprawiedliwej globalizacji. Propozycje usprawnień, PWN, Warszawa 2007 , s. 87 i n.

${ }^{27}$ Według zaleceń UE winna wynosić min. 60\% przeciętnej płacy krajowej.

${ }^{28}$ Por. T. Kowalik, Polska transformacja a nurty liberalne, w: Polska w gospodarce światowejszanse i zagrożenia rozwoju. VIII Kongres Ekonomistów Polskich, Warszawa 2007. 


\section{Tabela 1}

Stawki podatkowe w podstawowych podatkach bezpośrednich i pośrednich w krajach UE (porównanie z Polska)

\begin{tabular}{|c|c|c|c|c|c|c|c|}
\hline \multirow{2}{*}{ Lp. } & \multirow{2}{*}{ Państwo } & \multicolumn{3}{|c|}{$\begin{array}{c}\text { Wybrane elementy skali podatkowej } \\
\text { w podatku dochodowym od osób } \\
\text { fizycznych }\end{array}$} & \multirow{2}{*}{$\begin{array}{c}\text { Stawka } \\
\text { opodatkowania } \\
\text { dochodów osób } \\
\text { prawnych }\end{array}$} & \multicolumn{2}{|c|}{ Stawki podatku VAT } \\
\hline & & $\begin{array}{l}\text { Liczba } \\
\text { progów }\end{array}$ & $\begin{array}{c}\text { Stawka } \\
\text { minimalna }\end{array}$ & $\begin{array}{c}\text { Stawka } \\
\text { maksymalna }\end{array}$ & & $\begin{array}{l}\text { Podsta- } \\
\text { wowa }\end{array}$ & $\begin{array}{l}\text { Obniżona/ } \\
\text { Zreduko- } \\
\text { wana }\end{array}$ \\
\hline--- & Polska & 3 & 19,00 & 40,00 & 19,00 & 23,00 & 8 i 5 i 4 i 0 \\
\hline 1. & Austria & 4 & 0,00 & 50,00 & 25,00 & 20,00 & 10 \\
\hline 2. & Belgia & 5 & 25,00 & 50,00 & 39,99 & 21,00 & 12 i 6 i 0 \\
\hline 3. & Bułgaria & 4 & 12,00 & 32,00 & 34,00 & 15,00 & 0 \\
\hline 4. & Cypr & 3 & 20,00 & 30,00 & 10,00 & 15,00 & 5 i 0 \\
\hline 5. & Czechy & 4 & 12,00 & 32,00 & 24,00 & 19,00 & 5 \\
\hline 5. & Dania & 3 & 5,48 & 26,48 & 28,00 & 30,00 & 0 \\
\hline 6. & Estonia & 1 & 22,00 & 22,00 & 22,00 & 18,00 & 5 i 0 \\
\hline 7. & Finlandia & 6 & 0,00 & 32,50 & 31,00 & 22,00 & 17 i 8 i 0 \\
\hline 8. & Francja & 7 & 0,00 & 48,09 & 33,83 & 19,60 & 5,50 i 2,10 \\
\hline 9. & Gracja & 3 & 15,00 & 40,00 & 25,00 & 19,00 & 9 i 4,50 \\
\hline 10. & Hiszpania & 5 & 9,06 & 29,16 & 32,50 & 16,00 & $7 \mathrm{i} 4$ \\
\hline 11. & Holandia & 4 & 2,45 & 52,00 & 25,00 & 19,00 & 6 \\
\hline 12. & Irlandia & 2 & 20,00 & 42,00 & 12,50 & 21,00 & $\begin{array}{c}13,50 \\
\text { i } 4,30 \text { i } 0\end{array}$ \\
\hline 13. & Litwa & 2 & 15,00 & 33,00 & 15,00 & 18,00 & 5 i 0 \\
\hline 14. & Luksemburg & 10 & 0,00 & 38,00 & 29,63 & 15,00 & 12 i 6 i 3 i 0 \\
\hline 15. & Eotwa & 1 & 25,00 & 25,00 & 15,00 & 18,00 & 5 i 0 \\
\hline 16. & Malta & 6 & 0,00 & 35,00 & 35,00 & 18,00 & 5 \\
\hline 17. & Niemcy & 3 & 0,00 & 42,00 & 38,36 & 16,00 & 7 \\
\hline 18. & Polska & 3 & 19,00 & 40,00 & 19,00 & 23,00 & 8 i 4 i 0 \\
\hline 19. & Portugalia & 7 & 10,50 & 42,00 & 25,00 & 21,00 & 12 i 5 \\
\hline 20. & Rumunia & 1 & 16,00 & 16,00 & 16,00 & 19,00 & 9 \\
\hline 21. & Słowacja & 1 & 19,00 & 19,00 & 20,00 & 19,00 & Brak \\
\hline 22. & Słowenia & 3 & 10,00 & 40,00 & 19,00 & 20,00 & 8,50 \\
\hline 23. & Szwecja & 3 & 0,00 & 55,00 & 28,00 & 25,00 & 12 i 0 \\
\hline 24. & Węgry & 2 & 18,00 & 36,00 & 16,00 & 25,00 & 15 i 5 \\
\hline 25. & $\begin{array}{l}\text { Wielka } \\
\text { Brytania }\end{array}$ & 3 & 10,00 & 40,00 & 30,00 & 17,50 & 5 i 0 \\
\hline 26. & Włochy & 4 & 23,00 & 43,00 & 37,25 & 20,00 & 10 i 4 i 0 \\
\hline
\end{tabular}

Źródło: opracowanie własne na podstawie: www.mf.gov.pl; www.mojafirma.infor.pl (dostęp: 14.06.2013). 
Podatki dochodowe od wynagrodzeń pracowniczych są o tyle istotną kwestią że stanowią podstawowe (obok ubezpieczeń społecznych) narzuty na płacę netto pracowników - są więc elementem kosztów pracy. Na podstawie danych zaprezentowanych $\mathrm{w}$ tabeli 1 wysnuć można następujące wnioski:

- w UE z wyjatkami (np. Polska) dominuje egalitaryzm podatkowy przejawiający się w dużej dysproporcji w obciążeniu dochodów najsłabiej i najlepiej zarabiających przedstawicieli społeczeństwa,

- im mniejsze są obciążenia podatkowe najniższych progów, tym większe są obciążenia progów najwyższych,

- „spłaszczenie” struktury podatków występuje między 16 a 20\%, co oznacza, że ten poziom w wypadku podatku liniowego byłby uznany za właściwy.

$\mathrm{Z}$ danych zaprezentowanych $\mathrm{w}$ tabeli 1 wynikaja wnioski o bardzo dużej rozpiętości w podatkach (przede wszystkim bezpośrednich) w poszczególnych państwach UE. Ze względu na zagrożenie stąd płynące dla konkurencyjności własnych systemów podatkowych i dostrzegając fakt emigracji kapitału do nowo przyjętych w 2005 r. państw, Niemcy i Francja zagroziły w 2006 r. wstrzymaniem wpłat do budżetu UE do momentu ich zrównoważenia ${ }^{29}$.

\section{METODY TWORZENIA KONKURENCYJNOŚCI PODATKOWEJ PAŃSTW UE NA PRZYKŁADZIE POLSKICH SPECJALNYCH STREF EKONOMICZNYCH JAKO TYPU RAJU PODATKOWEGO}

Jak słusznie zauważyli Hans-Peter Martin i Harald Schuman ${ }^{30}$, współcześnie występuje zjawisko „przerzucania podatków” będące skutkiem dostrzeżenia przez korporacje szans związanych z wykorzystaniem różnic między poszczególnymi państwami, przede wszystkim w podatkach bezpośrednich. To już nie tylko poszukiwanie tańszych źródeł pracy czy tańszego pozyskania materialnych składników własnej działalności gospodarczej, lecz także sterowanie lokalizacją działalności gospodarczej tak, by w jak największym stopniu wykorzystać konkurowanie podatkowe poszczególnych państw między sobą.

Polityka bodźców podatkowych odgrywa szczególną rolę w dobie kryzysu przejawiającego się m.in. w ujawnianiu braków kapitalizmu, takich jak wzrost dysproporcji majątkowych między poszczególnymi grupami społecznymi, będący skutkiem występowania bezrobocia ponad jego naturalną wartość (zwłaszcza bezrobocia strukturalnego) ${ }^{31}$.

Ukierunkowywaniu migracji kapitału inwestycyjnego w Polsce służą SSE. Umożliwiają one prowadzenie działalności gospodarczej bez płacenia podat-

\footnotetext{
${ }^{29}$ Por. S. Owsiak, Harmonizacja podatków bezpośrednich warunkiem integracji gospodarczej Unii Europejskiej, ref. na VIII Kongres Ekonomistów Polskich, Warszawa 2007.

${ }^{30}$ Por. H.-P. Martin, H. Schuman, Pułapka globalizacji, Humanitas, Sosnowiec 2006.

${ }^{31}$ Por. T. Kowalik, Systemowe źródta obecnego kryzysu, „Master of Business Administration” 2009, nr 5 (97); P. Krugman, Jak powstrzymać kryzys, „Magazyn Idei Europa” z 6-7 grudnia 2008 r.; W. Szymański, Kryzys globalny. Pierwsze przybliżenie, Difin, Warszawa 2009.
} 
ku dochodowego (w ramach tzw. regionalnej pomocy publicznej), a na terenie niektórych gmin również zwolnienie od podatku od nieruchomości. Warunkiem jest tzw. nowa inwestycja, za którą uznaje się także wykupienie przez inwestora przedsiębiorstw w stanie likwidacji lub upadłości z zastrzeżeniem, że inwestorem jest osoba niepowiązana z wykupywanym przedsiębiorstwem.

W Polsce istnieje rozróżnienie terytorialne zgodnie z tzw. mapa pomocy regionalnej. W jej ramach podzielono terytorium kraju i wyszczególniono następujące „stawki” procentowe pomocy regionalnej do wydatków kwalifikowanych:

- 30\% (woj. mazowieckie) ${ }^{32}$,

- 40\% (woj.: dolnoślasskie, pomorskie, śląskie, wielkopolskie, zachodniopomorskie),

- 50\% (woj.: kujawsko-pomorskie, lubelskie, lubuskie, łódzkie, małopolskie, opolskie, podkarpackie, podlaskie, świętokrzyskie, warmińsko-mazurskie).

Przy obliczaniu maksymalnej kwoty zwolnienia podatkowego uwzględnia się koszty związane z nową inwestycją lub/i zatrudnieniem nowych pracowników do wysokości będącej iloczynem tzw. maksymalnej intensywności pomocy (zgodnej z powyższymi wskaźnikami procentowymi mapy pomocy regionalnej i wyższej z kwot: nowej inwestycji lub dwuletnich kosztów pracy nowo zatrudnionych pracowników. Przy czym dla nowej inwestycji minimalna wysokość kosztów musi wynosić 100 tys. euro.

\section{ZAKOŃCZENIE}

Występujące różnice w wysokości stawek podatkowych między poszczególnymi państwami UE są możliwą do wykorzystania przez prywatny biznes luką i mogą stanowić przesłankę dla lokalizacji własnej działalności gospodarczej. W tym aspekcie wskazaniami dla systemów podatkowych poszczególnych państw byłoby dbanie o niepodnoszenie stawek podatkowych. Takie działania widoczne sa w wypadku szeregu państw, w tym i Polski. Rekompensowane sa one zwiększonymi podatkami dochodowymi od pracowników. Ta tendencja stoi jednak w istotnej sprzeczności ze wskazaniami traktatu lizbońskiego (można je też wywieść jako sprzeczne z polską ustawą zasadnicza). To liberalistyczne swoiste „rekompensowanie” sobie przychodów przez budżet państwa ma charakter zachowań skandalicznych, zwłaszcza wtedy gdy dotyka ono osoby o najniższych dochodach i odbiera im podstawowe źródła egzystencji biologicznej. Nawet uznawany za klasyka i ojca liberalizmu Adam Smith zwracał uwage na potrzebę działań, które pozwoliłyby na odtwarzanie populacji robotników co najmniej w modelu rodziny $2+2$. Oznacza to, że dochody takiej rodziny winny być na poziomie co najmniej czterokrotności minimum egzystencjalnego. W tym aspekcie śmieszna jest tzw. polityka prorodzinna państwa - becikowe i podobne działania.

\footnotetext{
${ }^{32}$ Do 2010 r. było to $40 \%$.
} 
Wydaje się też istotne, by w przyszłości prowadzona była polityka ujednolicająca wysokość podatków bezpośrednich w ramach UE, co biorąc pod uwage fakt, że w UE dominuje solidaryzm społeczny polegający na braku lub minimalnym obciążaniu podatkowym osób uzyskujących dochody na poziomie minimum egzystencjalnego - byłoby korzystne dla najuboższych obywateli naszego kraju.

dr Leszek Michalczyk

Politechnika Krakowska

lmichalczyk@pk.edu.pl

\title{
ECONOMIC AND SOCIAL ASPECTS OF TAX COMPETITION IN THE EUROPEAN UNION
}

\begin{abstract}
Summary
In this paper, written with the premise of the migration of investment capital in globalising economy, differences in levels of taxation are discussed against the background of competition laws of individual member states aiming to maximise the volume of investment capital. Analysed from this aspect, realisation of European harmonisation projects which are in fact attempts at unification seems impossible. What is more, if the projects were to be realised, this would be disadvantageous to countries unable to compete for investment capital in a different way. Poland, which has neither the cheapest work force, nor the best infrastructure supporting business investing, is discussed in this context. Special Economic Zones that exist in Poland have been examined and related to some 'tax havens' of the Eurozone.
\end{abstract}


Copyright of Journal of Law, Economics and Sociology is the property of Faculty of Law and Administration of Adam Mickiewicz University in Poznan and its content may not be copied or emailed to multiple sites or posted to a listserv without the copyright holder's express written permission. However, users may print, download, or email articles for individual use.

Właścicielem praw autorskich do „Ruchu Prawniczego, Ekonomicznego i Socjologicznego” jest Wydział Prawa i Administracji Uniwersytetu im. Adama Mickiewicza w Poznaniu. Zawartość czasopisma nie może być kopiowana, przesyłana do innych stron internetowych bądź zamieszczana na blogach bez pisemnej zgody wydawcy. Niemniej artykuły można drukować, kopiować lub przesyłać w formie elektronicznej na własny użytek. 